Sultan Qaboos University Journal of Arts \& Social Sciences

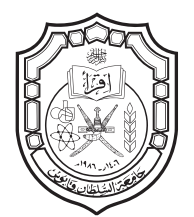

جامعة السلطان قابوس الإدابعاب

مجلة الآداب والعلوم الاجتمأعية

\title{
Religious Social Media Activism: A Qualitative Review of Pro-Islam Hashtags
}

\author{
Iman Mohamed Mohamed Zahra \\ Assistant Professor \\ Mass Communication Department \\ College of Arts and Social Sciences \\ Sultan Qaboos University \\ imanz@squ.edu.om
}




\section{Religious Social Media Activism: \\ A Qualitative Review of Pro-Islam Hashtags}

Iman Mohamed Mohamed Zahra

Abstract:

There have been so many acts of terrorism connected to radical Muslims that it's not surprising Islam has a public relations problem. Pollsters, historians and other experts say that the West's collective instincts toward Islam have been shaped over decades by a patchwork of factors. These include demographic trends, psychology, terrorism events, foreign policy, domestic politics, media coverage and the Internet. Therefore, it is not surprising that Muslims are the most negatively viewed faith community in some countries as the United States. The objective of the current research is to review qualitatively the social media platforms of the hashtag \#Notinmyname, initiated by renowned Muslim British Community namely Active Change Foundation as a successful model of social media activism combatting the worsening image of Islam. The major conclusion of this study is that hashtags launched by Muslim activists derive from the social media platforms exacerbating and unprecedented power to stir political and social movements especially, regarding controversial and stagnant matters. Posts, comments and shares on different social media platforms go viral, stir discussions and trigger public opinion. These \#hashtags were not a launching base for a pro-Islam campaign only, as much as being an outlet breather for all pro and anti-opinions regarding Islam. Social media are now the pathway to mobilize the crowd online to take an action in the real world.

Keywords: Constraints; Rules; Relative Clause; C-command.

\section{النشاط الديني على شبكات التواصل الاجتماعي الالكترونية: دراسة تحليلية كيفية للوسوم الموالية للإسلام \\ إيمان محمد محمد زهرة}

ارتبطت الكثير من أعمال الإرهاب بالمسلمين الراديكاليين لدرجة أدت الي معاناة الدين الاسلامي من صورة نمطية الإنية سلبية. يؤكد الباحثون

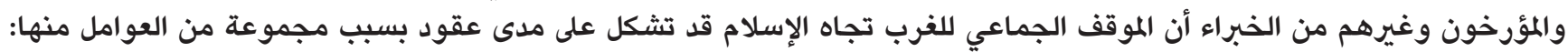
الديموغرافيوالنفسي، ومنها ما يتعلق بالهجمات الارهابية والسياسة الخارجية والسياسة الداخلية والتغطية الإعلامية والإنترنت الإنتان

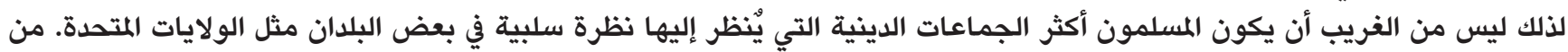

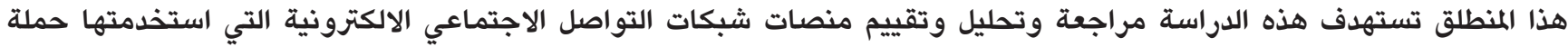
هinotinmyname

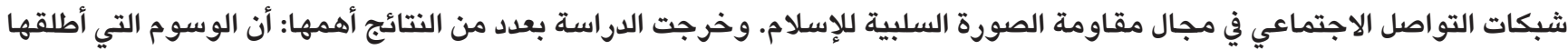

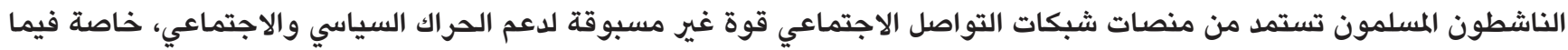

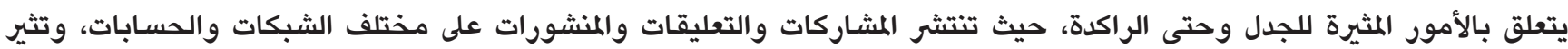

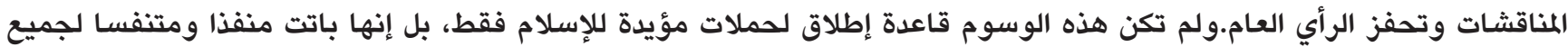
الأراء المؤيدة والمعارضة للإسلام، حيث تعتبر شبكات التواصل الاجتماعي في الوقت الراهن الطريق لتعبئة الحشود عبر الإنترنت لاتخاذ الإنات إجراءات فعلية في العالم الحقيقي. 


\section{Introduction}

There have been so many acts of terrorism connected to radical Muslims that it's why, it is not surprising Islam has a public relations problem. Pollsters, historians and other experts say that the West's collective instincts toward Islam have been shaped over decades by a patchwork of factors. These include demographic trends, psychology, terrorism events, foreign policy, domestic politics, media coverage and the Internet. Therefore it is not surprising that Muslims are the most negatively viewed faith community in some countries as the United States (Talev, 2010).

The Internet and social networking applications have bypassed the traditional media filter and magnified the influence of fringe activists on public perceptions of Islam (Talev, 2010). Online communication platforms have become a staple for terrorist organizations who are taking advantage of the fruits of globalization and modern technology - especially the most advanced communication technologies - to communicate, seduce, plan, and coordinate their deadly campaigns (Aly, 2012).

With such terrorist groups as ISIS, using social media campaigns extensively including online magazines, recruiting videos featuring narration in Americanaccented English and even video games (Hoskinson, 2014); Muslims then started using social media to condemn ISIS, fight Islamophobia and most of all launch media campaigns denouncing those groups and denying exploiting Islam in this outrageous form. Social networks (SNS) are not only a central platform in the PR effort opposing ISIS, but also an important tool that ISIS itself uses for both psychological terrorism and recruiting activists. However, as the media presence of ISIS grows, so do the voices of young Muslims around the world who transmit an unequivocal message both to the West and ISIS rejecting the organization and anyone who would join its ranks (Barak, 2014).

The current research will be divided into two parts: the first part presents a review of previous and upcoming campaign hashtags as a theoretical framework and review of literature. The second part tackles the major findings regarding analysis of social media platforms. Conclusion will follow.

\section{Theoretical framework and literature review} Activism via Social Media

Social Media accounts are important in coordinating activism, and the challenges of building and maintaining strong connections. Social media have enabled the explosion of dialogue and information sharing by both proponents and critics (Brikner, 2016). Social media are rapidly evolving, requiring a responsive and flexible approach when used for campaigning. Uniquely, Twitter for example offers a direct means of communication with hard-to-reach targets, such as celebrities, creating access opportunities that were previously difficult to imagine. Another advantage of social media is that it is possible to track how information is being shared, and then monitor audience reaction as Tweetreach to track and analyze the effect of our social media advocacy. The open accessibility of Tweetreach and Twitter means that it is possible to see who has engaged with information and their responses, allowing campaign information and strategies to be amended and tailored in real time (Helfer et al., 2013).

Islam is a religion of mercy for the entire humanity. It is imperative to present the true picture of Islam, and for this we have to employ all the advanced means of modern information technology and promote Islam on social media (Al- Hamid, 2012). Uddin (2014) wondered whether: 'hashtag activism' is doing enough to stop bad speech about minority communities and affect social change? Social media accounts by members of minority communities are responding to racism and stereotyping in the media, and getting results. The online Muslim community has demonstrated its ability to identify and counter harmful speech, but it needs to take the next step and seek more constructive and productive solutions. Instead of taking to the streets, Muslims are rallying on Twitter, Facebook and Tumblr. Social media are helping Western Muslims for instance to embrace and reflect the culture of self-expression to counter bad speech.

Pro-Islam hashtags related to counter terrorism campaigns

The \#NotInMyName movement is not the first time that Muslims have spoken out against terrorist organizations, though it may feel like it for some people. The Vatican has reported that the secretary general for the Organization of Islamic Cooperation stated that ISIS "has nothing to do with Islam and its principles that call for justice, kindness, fairness, freedom of faith and coexistence." Egypt's highest religious authority has also denounced ISIS as a group that violates Sharia and humanitarian law. These messages were not accompanied with trendy hashtags, so the well-meaning declarations may have 
fallen on deaf ears (Sisto, 2014).

Results definitely suggested the existence of other campaign attempts aiming at the image restoration of Islam, although mostly lacking organizational and unified perspective. Over the years many individual and group attempts were spotted to modify the distorted image of Islam either online or offline. Many online campaign hashtags launched via different organizations preceded, aligned with or followed \#Not in my name, although mostly not that successful and gaining far less coverage.

Some of these attempts were:

As early as 2010, Exploring Islam British Foundation used social media via Facebook and You Tube to launch a campaign to improve the image of Islam after an opinion poll found that more than half of British people associate the religion with extremism and terrorism.

"Inspired by Muhammad" aimed at promoting Islam as a faith which contributed positively to British society. Posters of Muslims with captions like: "I believe in rights for women... so did Muhammad" featured at bus stops, Tube stations and on London cabs.

A website, www.inspiredbymuhammad.com, provided online support for the campaign by hosting straightforward information about Islam, Muhammad and British Muslims (Inspired by Muhammad.com).

In 2012 in the US, a month after an ultra-conservative group plastered controversial "Defeat Jihad" ads on 10 CTA buses and likened Muslims to "savages," a local Muslim group countered back with a campaign to "reclaim Islam" and educate the country about the true meaning of the word "Jihad."

Through CTA bus and train ads and a social media campaign on Twitter, Facebook and YouTube, participants were being asked to express what their Jihad is with the hashtag \#MyJihad (Sfondeles, 2012). The response to the Twitter campaign has been "mindblowing," with tweets pouring in from Australia, England, the Middle East and South Asia. It also gained support on Facebook from organizations such as Americans Against Islamophobia (Madhu, 2012).

The campaign was revived once more in September 2014 as Chicago-based organization and public education campaign, MyJihad, announced their condemnation of the extremist group, "ISIS" or "ISIL" and encouraged all Muslims globally to openly condemn this group and any similar groups.

The declaration comes after numerous Muslim organizations in the U.S. and around the world that include Muslim clergy, have come forward to publicly denounce the actions of the ISIS group following criminal acts of persecution and murder against Christians in Iraq as well as Yazidis, Muslims and other innocent people, in addition to the tragic beheading of American Journalist, James Foley (About The MyJihad Campaign, http://myjihad.org(/. Council on American-Islamic Relations (CAIR) the initiator of this and several other campaigns, believed the rationale behind the national initiative was not only to foster a more positive public perception of Islam but a deeper faith among Muslims (Tilson, 2011).

In Canada and inspired by \#NotInMyName (as happened with other Arab countries campaigns as well) the Ahmadiyya Muslim Community launched a similar social media campaign in October 2014 under the title "Stop the Crisis" with proposals of how to deal with the challenge of radicalization including: education, open dialogue and finding solutions for the ISIS crisis (Barak, 2014).

In 2014 The American "Take on Hate campaign" has been pushing back against bigotry by correcting the false light placed on Arab and Muslim Americans. Those who monitor bigotry can barely keep up with Islamophobia fueled by politicians and media pundits. Starting Feb. 8 through Valentine's Day 2016, the group launched a social media campaign, "Take on Hate with Love", to showcase the contributions of Arab and Muslim Americans (Khalifieh, 2016).

In December 2015, The Ahmadiyya Muslim Community of USA launched an unprecedented and comprehensive campaign to separate True Islam from extremism. The True Islam and the Extremists campaign educated Americans and Muslim Americans on the peaceful, anti-extremist teachings of Islam by clarifying 11 of the most common misconceptions extremists use to radicalize youth.

The Community extended invitations to over 2,100 Muslim American Imams and thought leaders to endorse the Campaign to demonstrate True Islam and advance this proven model to combat extremism. The Campaign was publicized through press conferences, flyer distributions, meetings with members of local, state, and federal government, opinion editorials, television and radio interviews, interfaith dialogues, public lectures, university hosted debates, and the public invitation to all Americans and Muslim Americans to join through social media (http:// trueislam.com/home/).

Other campaigns followed the same path, but were not fully documented. 
Literature contribution

Past research concentrated mainly on the evolving nature and effects of social media usage as a main launching pad of different activism campaign hashtags. From reviewing past literature, the researcher noticed that while abundant theoretical research tackled the matter of violent extremism via social media and methods to counter this sort of violent extremism known as CVE (Helmus et. al., 2011; Aly, 2012), no research actually analyzed the role of social media activism campaigns or campaign attempts to combat extremist and terrorist activities. Nevertheless, lots of research tracks have been discovered that will be dealt with hereafter.

Ameripour et. al. (2010) discussed the usage of social media in Iran to launch Conviviality campaigns and found out that Internet conviviality cannot be treated as an independent variable with deterministic outcomes on society, but as a technology that is shaped by ongoing economic and political forces.

Furlow (2011) found out through analyzing three cause related marketing campaigns via Facebook that they have effectively reached their target audience through social media.

Özdemir (2012) analyzed the social media green campaign Yemezler! launched in Turkey as an advocacy PR campaign and proved effectiveness and feasibility for NGOs. Through an advocacy PR campaign on Twitter in both US and Canada Brickner (2016) analyzed educator's care.

Health care campaigns via social media gained lots of attention. Pillai (2012) tackled the issue of healthcare campaigns via social media. Cameron et al. (2013) tackled the effect of social media campaigns via Facebook on organ donation. Livingston et al. (2014) studied effects of a social media intervention campaign on the attitudes of young people towards mental health issues. Dowshen et al. (2015) discussed the effect of social media on promoting getting tested for STDs among American adolescents. Jawad et al. (2015) revised a social media campaign on water pipe smoking hazards. Dunlop et al. (2016) studied utilizing social media campaigns in promoting healthy eating habits similar to Huesch et al. (2016) research on public heath social media campaign.

Ketterand Avraham (2012) found out that during analyzing 10 place branding social media campaigns, that the distinction between the components of source, message and receiver fades as users gain more power and take an active role in the creation and distribution of campaign messages.
Political campaigning via social media gained lots of focus as to glamorize mostly its effects. The "Israel Loves Iran" and "Iran Loves Israel" Facebook campaigns came about in March 2012 as means to counter the pro-military rhetoric emanating from both the Israeli and Iranian governments and has been a subject to extensive study (Kuntsman and Raji, 2012). Ahmad and Sheikh (2013) discussed the role of social media campaigns in triggering youth political participation among university students. Aragon et al. (2013) studied political social media campaigns in Spanish elections of 2011. Carlson et al. (2014) discussed political campaigning via blogging in Finland. Wells et al. (2014) compared social media usage between US and French presidential campaigns in 2012. Hagar (2014) discussed municipal election social media campaigns in Canada. Spierings and Jacobs (2014) discussed the role of social media campaigns on preferential voting.

Other types of activism research on religious usage of social media were spotted though, including Finnigan and Ross's paper (2013) on Mormon feminists' usage of social media through Facebook and blogs from 2004 to 2013 to connect with one another and navigate potential pitfalls in religious feminist activism.

It was apparent that past research recognized the maximum importance and effectiveness of social media in launching successful campaigns, but some warned about the failure to control messages which might lead to inevitable problems. Researchers can't deny though, that the rapid development in Internet technologies provided new tools for campaigns. Social media in particular reduce dependency on mass media; enable organizations to reach larger stakeholders and provide a platform for developing two-way, communication with stakeholders; thus facilitating participation.

Majorobjectives and research questions:

The objective of the current research is to review qualitatively the social media platforms of the hashtag \#Notinmyname, initiated by renowned Muslim British Community namely Active Change Foundation (ACF) - to launch their pro-Islam and anti-extremism campaign - as a successful model of social media activism combatting the worsening image of Islam, through linking it with extremism as alleged by haters. \#NotInMyName campaign hashtag was chosen as a successful modelof pro-islam hashtags to be analyzed, for its apparent success in gaining worldwide attention of at least 85000 people and 14000 tweets 
in less than a week from its launch early September 2014 , converting it from a local community campaign hashtag to being honorably mentioned by former American President Barak Obama - when addressing the UN general assembly - and former UK Prime Minister David Cameron as well (Hausam, 2014; living safe together Australian report). The research qualitatively reviews \#NotInMyName social media accounts via Twitter, Facebook, Instagram and You Tube in a time period extending from Paris Attacks dated 13/11/2015 till 15/6/2016 three days past Orlando Shooting. This time frame was purposively chosen due to Islamic extremism escalating attacks on civilians all over the world during this time period, that also witnessed Muslim activists' attempts to modify the highly negative image of Islam via substantive social media efforts.

This effort comes to consider the role of social media to reinforce the true image of Islam as a counterreaction to "focused attention on Islamic extremist content on the Internet". The increasing use of social networks by both sides demonstrates that it is a key arena in the battle for Muslims around the world (Barak, 2014).

The current research poses two major research questions as follows:

1. Has there been any attempts to restore the image of Islam and combat extremism through social media campaignhashtags other than \#Not in my name?

2. How are \#NotInMyName social media accounts utilized to act as pro-Islam platforms?

Research methodology and sampling procedures: This research is an exploratory attempt to qualitatively analyze \#NotInMyNamesocial media accounts through a detailed study of the campaign usage of social media platforms. \#NotInMyName social media accounts are subjected to detailed scrutiny to determine their purposes and general usage via followers.

The campaign messages were originally launched via the hashtag in September 2014 by Young British Muslims of the Active Change Foundation, then revived immediately after Paris attacks in November 2015.

The qualitative review of the social media accounts of \#Not in my name campaign includes the following platforms: Twitter, Facebook, Instagram and YouTube. The main website of the campaign www.isisnotinmyname.com set in September 2014 mentioned three links to a Facebook, Twitter and You
Tube accounts. These accounts turned out to be the official accounts of the Active Change Foundation (ACF) the British Muslim Organization that launched the campaign in the first place.

Their Facebook page was liked by 7,367 people until $15 / 6 / 2016$ and had all sorts of posts on the activities of the charitable organization, news of Muslims in Europe and USA and news and footage of the campaign.The same applies to their twitter account including 2,995 tweets and followed by $30.6 \mathrm{~K}$ followers until the same time period, including nearly the same material as the Facebook account.The You Tube channel of ACF contained 44 videos with 926 subscribers. The videos uploaded on the account were footage of the campaign, introduction to the foundation, its founder and different activities of ACF.

The researcher though resided to qualitatively analyze \#Notinmyname accounts on Twitter, Facebook, Instagram and You Tube, rather than analyzing the pages of ACF on the same platforms, since the main purpose of this research is exploring the campaign accounts not exploring the foundation behind the campaign. The campaign official hashtags included so much more information and interactivity than the ACF pages.

\section{Rationale behind utilizingqualitativeanalysis}

$\neg$ Many reasons lie behind executing the qualitative analysis on the chosen sample, partially related to the sensitivity of the issue and partially related to the hashtag subject to study.

As per past research (Zahra, 2018), ACF called on Muslims around the world to join together in order to bring an end not only to ISIS and its activities, but also to the radicalization it represents. Since then, Muslims from all over the world have taken to social media to protest against the Islamic State militant group, saying the extremists do not represent Islam, posting messages on Twitter and other social media platforms denouncing ISIS' actions as un-Islamic, with the hashtag \#notinmyname.

In a comment on the hashtag, Essert (2014) said: "It's a simple but to-the-point hashtag that does an excellent job of summating one of the biggest problems of the increasing popularity and notoriety of the Islamic State: a glaring misrepresentation of an entire faith. As much as the Islamic State wants to claim it's defending its religion and people, the fact of the matter is that it's not, and it's very important for people to clearly see the difference between the Islamic State terrorist group and the Islamic religion". 
Former President Barack Obama singled out this powerful \#hashtag rejecting the actions of Islamic State militants and cited \#notinmynamestarted by the ACF who have come together to take a stand against brutal violence espoused by the terror group; instead spreading a message of peace online, using the same social media platforms that the terrorist group are using to propagate hate - and it hasn't gone unnoticed by the President of the United States at the time (Meredith, 2014).

In July 2015, a follow up \#hashtag was launched by ACF encouraging people to tell militants from the socalled Islamic State terrorist group exactly what they think of them. The Active Change Foundation (ACF) encouraged social media users to use \#MessageTolsis alongside tweets, selfies, vines and any other formats to give the terror group a piece of their mind and show that they are not scared of them. (Harris, 2015). \#NotInMyName\#hashtag was revived strongly following Paris Attacks in 13/11/2015. "As the terrorist attacks erupted in Paris, people throughout the world mourned with France, and appalled Muslims turned to social media using the hashtag \#NotInMyName" (Pratt, 2015). Reviving the \#NotInMyName hashtag, many Muslims are sending messages and posting images that ISIS, the group claiming responsibility for the attacks that killed over 129 people and left 352 injured, does not represent Islam (Brown, 2015; Faget, 2015).

Since then Muslims worldwide have resided to the hashtag to condemn and denounce every terrorist attack launched under the name of Islam. Finally wrapping up (due to the time period of the current research analysis that ends 15 June 2016) with Orlando Shootings Sunday June, 12 after which Social media have been ablaze with posts bearing the hashtag \#NotInMyName, with Muslims across the world calling for peace and refusing to be stereotyped after the devastating Orlando attacks. In the aftermath, many Muslims took to Twitter and Instagram to express empathy for the victims using the hashtag \#NotInMyName. The hashtag, which has been used after previous hate crimes, is a reminder that violence is not condoned in the religion (Glover, 2016; Gouveia, 2016).Qualitative analysis, then emerged as the only possible option to undergo the current research for matters of complexity, overlapping incidentsand the multiplicity of terrorist attacks during thistime frame.

\section{Major Findings}

The next part presents the major findings regarding the qualitative analysis of \#NotInMyName official accounts via Twitter, Facebook, You Tube and Instagram as follows:

A review of \#Not In My Name Twitter account The current research reviewed the twitter account that launched "Not In My Name Campaign" under the same hashtag.The review occurred systematically on weekly basis starting 20/11/2015 after the news about the campaign on CNN and how it was revived just the second day after Paris attacks that took place Friday $13 / 11 / 2015$. The review was finalized $15 / 6 / 2016$ three days after the Orlando shooting. The time span covered by the analysis included all the tweets and retweets sharing personal views, news, information, photos, videos and vines posted onto the hashtag starting $14 / 11 / 2015$ the first day of the campaign revival and ending 15/6/2016. The reason behind choosing this particular wrapping up date was the massive western reaction on the Orlando shooting that took place 12/6/2016 and resulted into the death of 49 people who were present in the Pulse nightclub at the time.

Qualitative analysis of the hashtag revealed some interesting findings presented hereafter:

1. \#NOTInMyName was never an account launched from the start to display footage regarding campaign contributors expressing their resentment to ISIS's deeds and terrorist attacks. Rather it turned out to be a rich platform concerning controversial debates on Islam, Muslims, refugees and various governmental actions as will be detailed hereafter.

2. Footage from the campaign including the campaign main video (posted when the campaign first started in September 2014) was tweeted and retweeted extensively by different individuals and groups starting 14thNovember 2015 the day when the campaign was relaunched. The following two days 15 and 16 November haven't only witnessed maximum retweeting, but also the campaign's main video was subtitled into different languages. Tweets accompanying the campaign videos were mostly detaching ISIS from Islam and Muslims for example: "Because ISIS not Muslims represents hate" or "ISIS do not represent British Muslims"... etc.

3. The maximum retweeting of the videos especially the main video continued vigorously until $26 / 11 / 2015$, which represented the peak of the campaign. Twitter Reverb which is a visualization tool from Twitter, built with periscopic elaborated 
that starting Friday the night of the attacks until Tuesday 17/11/2015 the twitter hashtag was used 94 thousand times (Brown, 2015). Analyzing the reverb, the researcher found out that the maximum tweeting on the account was 91 tweets per minute on Tuesday 17/11/2015 at 9:26 am EUT.

4. The process started to decrease gradually to be retweeted scarcely on the hashtag in the upcoming months in an irregular rhythm denying the campaign the consistency feature that presents one of the main pillars characterizing any campaign. Footage from October 2014 showed that the campaign was being supported by 85647 voices and counting (without further updates) and the hashtag was trending among the top 10 hashtags in Europe in different time intervals (for example in Denmark in January 2016).

5. The hashtag referred since (18/9/2014) to a website of the campaign (www.isisnotinmyname.com), another page on Facebook and a youtube channel that will be reviewed hereafter. This website was launched since launching the first phase of the campaign in September 2014. People tweeted their admiration and support of the campaign, but some tweeted: "why so late? Violent Islamism didn't show its ugly face since yesterday".

6. Even the campaign heading "Not In My Name" was used to launch footage shot via similar technique condemning different political governmental actions as the footage that was shot to condemn Australian governmental actions towards banning refuge or to denounce European politicians sending back refugees to Turkey. The heading of the campaign was used as an international icon in itselfsymbolizing denouncing every action that was a disgrace in one way or another from the viewpoints of followers of the hashtag.

7. Not only footage, but the heading itself "Not in my name" was used extensively as a motto to launch different opinions in different matters that followers condemn, so "Not in my name" was used as a motto to combat racism in South Africa in tweets starting $1 / 3 / 2016$, also used as a motto to condemn bullying at schools and used as a motto by Danish citizens in their campaign "Shame on Denmark" denouncing the acts of Denmark in banning refugee entry to its territories.

8. Actually the heading of the campaign was used as a title to two songs, one denouncing the acts of the British government cutting budgets, privatizing health care and de-subsidizing disabled and the second by the metal band "Ashestoangels" denouncing wars and accusing war initiators of having blood on their hands. The two songs were tweeted and retweeted on the hashtag in multiple occasions.

9. \#NOTInMyName account was used extensively to condemn all terrorist attacks undergone by radicals paying allegiance to ISIS. These condemnations initiated with Paris Attacks, continued with Belgium Attacks and lately expressed by Muslims all over the world to condemn Orlando nightclub shooting, the deadliest mass shooting in the U.S. history as per the news posted via the account "Muslims are taking Twitter to express empathy for the victims by tweeting messages with \#NOTInMyName". Following such incidents tweets and retweets reach the top notch multiplying franticly as compared to normal days, when tweeting and retweeting on other matters related to Islam including refugees and launching war on Muslim lands prevail. Every time a terrorist attack happens or a massacre by the hands of a Muslim, the main video of the campaign and other productions are tweeted massively to condemn the attacks as a sort of a Reactive Strategy towardsthese horrifying events.

10.Several hashtags followed the footsteps of \#NOTInMyName condemning the acts of radical Islam launching different terrorist attacks; and were mentioned in the hashtag of the campaign. Examples included and were not confined to: \#NothingToDoWithlslam \#MuslimsAgainstlsis \#NotAllMuslims \#YouAintNoMuslimBruv \#TerrorismNotlslam \#No2lsis \#WeWantPeace and \#ThislsNotlslam. \#NoEnminombre is a Spanish hashtag bearing the same name of the campaign in Spanish and expressing the same viewpoints. In the aftermath of Orlando Shootings several hashtags were launched by different Muslim Activists condemning the attacks and detaching Islam from such assassins in a killing spree. Those hashtags were mentioned on \#NOTInMyName account including \#Muslim and \#MuslimsStandWithOrlando.

11.\#NOTInMyName was a platform of different views regarding Islam and Muslims. Muslim haters expressed their anger regarding Islam as a religion of peace. They showed that Muslims commit crimes under the name of Islam then apologize through hashtags as \#NOTInMyName. On the other hand 
Muslims and Sympathetic non-Muslims defended Islam and the hashtag. American footage was shot in the same style as \#NOTInMyName videos in response to the endeavors of such campaigns supporting the diversity of the American community.

12. Several political, social and economic issues were discussed using the hashtag, as if \#NOTInMyName as many similar twitter accounts were set to be an uprising platform against all unjust actions taking place in different parts of the world. Tweets, retweets, news, photos, videos, vines and caricature in many languages, but mainly English, Arabic, French and Spanish tackled many controversial issues including Trump's views, children's suffering, British budget cuts, refugee entry denial, bombing Yemen, Syrian war, troubles in Libya and voting against disability support. Several hashtags were also mentioned on the twitter account that link followers to such situations discussed especially the refugee matter that was often discussed during the review period (\#LetThemStay and \#RefugeesWelcome were just examples).

13. The emotional appeals were extensively apparent in all media displayed through the hashtag. Tragic pics of children, horrifying videos of bombings and massive fires were displayed especially related to certain issues as child refugees banned from entering Britain. Strong language was used as well including: powerful phrases describing Australia for example as "Disgracing Humanity", speaking on the behalf of Europe as "I am Europe and I say no to the refugees", "Offer Sanctuary for People Seeking Asylum" or addressing terrorism as "Stop Hijacking Islam to promote your terrorism".

14. News from all over the world in different languages was posted on the hashtag, some discussing the campaign especially after the different terrorist attacks or other crucial events under headlines as: "Muslims launch powerful social media campaign against ISIS with \#NotInMyName" or "Muslims are taking Twitter to express empathy for the victims by tweeting messages with \#NOTInMyName hashtag " or "People have taken to Twitter to show their anger at the U.K.'s airstrikes in Syria using \#NotInMyName". News on all the other issues discussed via the hashtag as refugee problems, governmental problems and election problems were also posted frequently. News on certain related events was also posted as the Islamic
Awareness Week in Britain dated 21/3/2016 or News on lectures held to defend Islam as "\#NotInMyName: Muslims Respond" held by Salim Al-Marayati the president of Muslim Affair Council in Indiana, US dated 18/5/2016.

\section{A review of \#NotInMyName Facebook Page}

The current research reviewed qualitatively the campaign page on Facebook. The Facebook page was not well known as the twitter account or publicized as much. The researcher tracked the same time interval and procedures as happened with the twitter account and deduced the following results:

1. The Facebook page of the campaign is a miniature copy of the main twitter account. As mentioned before, \#NOTInMyName twitter account turned out to be a rich platform concerning controversial debates on Islam, Muslims, refugees and various governmental actions. On the contrary, most of the posts on the Facebook page included footage from the campaign and news about the campaign in the form of articles and videos in large proportions since launching the campaign back in September 2014 then reviving it the day following Paris attacks, and continuing until Orlando Shooting. Maybe the reason behind maintaining a less viable Facebook page is that twitter was the major platform of the campaign in the first place, even lots of articles mentioned twitter as being the main platform of the campaign: "\#NotInMyName: Muslims condemn IS through Twitter campaign" (SBS Network, 2015). The other reason resides in the nature of Twitter itself being a platform for every heated controversial issue worldwide.

2. Although the Facebook page was less active than the twitter account, they shared some similarities, one of the most important was: "Not in my name" being used extensively as a motto to launch different opinions in different matters that people condemn on the page, so "Not in my name" was used as a motto to denounce UK's airstrikes on Syria or Trump's hate speech of Muslims after Orlando shooting by members of LGBT declaring that he doesn't speak in their name. News on these other matters was posted all around the Facebook page.

3. Another point of similarity comes from the page being used as a platform of discussing several political issues, as if \#NOTInMyName was set to be an uprising platform against all unjust actions taking place in different parts of the world, but not 
with the same strength or frequency as the twitter account. Several controversial issues were tackled including Trump's views of Muslims in the US, children's suffering in Syria, condemning British decision to bomb Syria, refugee entry denial and asylum refusal, Gaza problems and defending Islam. In covering those issues different languages were used same as the Twitter account.

4. The major finding was that the coverage of the campaign was more effective than the campaign itself, and that's the advantage of stirring issues via social media and this fact was apparent especially through Facebook where hundreds of articles on the campaign and Muslim solidarity moves were posted.

\section{A review of \#Not In My Name You Tube Channel} The current research reviewed qualitatively the campaign You Tube Channel. The researcher tracked the same time interval and procedures as happened with the twitter and Facebook account and deduced the following results:

1. The Channel included 5 top videos including the major video of the campaign published on September 10, 2014 by the Active Change Foundation. This video was top notch viewed by $902 \mathrm{~K}$. The other four videos were discussing the campaign or discussing issues connected with Islam like the alleged violence and Jihad.

2. The channel also contained 13 new videos until $15 / 6 / 2016$. Not a single video of the latest ones was an official \#NotInMyName video. Rather, these were videos either defending the true essence of Islam, or spreading awareness of the religion. Other Not In My Name individual videos were produced by individuals and local communities inspired by the campaign using the same production style of ACF and Not In My Name motto to condemn attacks on Islam or to show that Muslims lead normal lives. Other videos used Not in My Name motto also embedded in songs condemning Paris attacks as an example. Different languages were used in those productions beside the English language.

3. The rest of the results were 123 videos in different languages. The videos can be assembled under four major categories:

a) Campaign videos subtitled in different languages or videos on the campaign either news or analysis videos in different languages as well ensuring the internationalization of the campaign. b) Videos inspired by the campaign but not produced by ACF, using the heading of the campaign to denounce terrorism, show the true essence of Islam and send messages of resentment to ISIS as has been requested by the campaign initiators. Those videos used different languages as well, widening the effect of the campaign to the maximum even though those were not official videos, including some songs as well as "Not in my name" song by Sami Yusuf denouncing ISIS acts of terror.

c) Videos explaining the true message of Islam as the solidarity and peace religion, either through debates, lectures or cultural activities. Under the same category comes news and analysis videos on Islam as a religion with people for and against the religion. Opinions are being expressed featuring individual viewpoint.

d) Last but not least as happened before via both Twitter and Facebook, the channel was being used as a platform of discussing several political and social issues, as if \#NOTInMyName was set to be an uprising platform against all unjust actions taking place in different parts of the world, using the growing availability of user-generated viral videos discussing all sorts of controversies, condemning British decision to bomb Syria, refugee entry denial, asylum refusal problems and different health problems. Some of those videos used the heading of the campaign "not in my name" and some not.

4. The major finding was that the coverage of the campaign was more effective than the campaign itself, and that's the advantage of stirring issues via social media and this fact was apparent through different social media platforms, maybe one more prominent than the other.

A review of \#Not In My Name Instagram Account The current research reviewed qualitatively the campaign page on Instagram during the same time interval following the same procedures as happened with Twitter, Facebook and You Tube and deduced the following results:

1. Until 15/6/2016 \#Notinmyname Instagram account contained 31 thousand and 513 posts and through the pics, videos and comments, the account turned out to be a rich platform concerning controversial debates on Islam, Muslims, refugees and various governmental actions, especially the war on Syria that was launched as a reaction to Paris attacks. 
2. Photos and footage from the campaign itself were posted onto the account after tragic terrorism hits, as Paris attacks, Brussels attacks and Orlando shootings extensively, as happened with the rest of the accounts.

3. Pics with comments in different languages, criticized and incriminated UK's airstrikes on Syria, Trump's hate speech against Muslims, murder of children during the war and refugee entry denial... etc.

4. Although some of the pics posted on Instagram were shared via Facebook and Twitter as well, the abundancy of pics tackling a certain matter as the war on Syria whether symbolic or real pics had a very strong effect on followers and that became obvious in the numbers of likes, shares and different comments.

5. Similar as Facebook, Twitter and You Tube "Not in my name" was being used extensively as a motto to launch different opinions in different matters that people condemn on the page, so "Not in my name" was used as a motto to denounce UK's airstrikes on Syria or Trump's hate speech of Muslims or bigotry against Muslims or killing children in war. "Not in my name" symbolized activism against all unjust actions and the motto itself was drawn and photographed in different colors and effects and posted all over the account.

6. Most pics and footage posted held opinions pro-Islam, but some held opinions anti-Islam as happened with all accounts per mentioned.

7. Pics and footage differed in the appeals used, some hilarious using the humor appeal through mocking the status-quo, others sharply criticizing the political situation and ones terribly tragic portraying horrifying images especially those of dead and injured children during attacks on different Arab states especially Syria.

8. The major finding depicted here was that \#Notinmyname via Instagram acted as an activism arena of all unjust causes of the world through pics that are more powerful than a thousand words. British, European, American, ISIS and Middle East issues were discussed under the heading "notinmyname, making the heading of the campaign more powerful than the campaign itself and lasting through social media even after the campaign activity ended.

Based on the previous analysis, the following discussion will hold the answer to the two key research questions followed by a general conclusion.
RQ1: Has there been any attempts to restore the image of Islam and combat extremism through social media campaign hashtags other than \#Not in my name?

Results definitely suggested the existence of other campaign attempts aiming at the image restoration of Islam, although mostly lacking organization, unified perspective and message consistency. Over the years many individual and group attempts were spotted to modify the distorted image of Islam either online or offline. Many campaigns launched via different organizations preceded, aligned with or followed \#Not in my name campaign, although mostly not that successful and gaining far less coverage.

- Some campaigns backlashed prompting angry responses, as Bernstein (2015) recited that a previous unsuccessful ICNA billboard campaign in 2013 that invited Americans to see similarities between Christianity and Islam and another campaign my jihad backlashed, leading in the case of "My Jihad" to erect billboards linking Islam with violence. This is expected due to the scattered nonunited efforts of different Muslim charities using social media platforms without previous planning.

- Social media campaigns have a different definition than the traditional definition previously implemented to organize campaigns, as Zimmerman and Brown (2012: 289) asserted that a social media campaign is a systematic course of aggressive activities used to attain more likes for the account. Using such criteria one can deduce the extreme success of \#NotInMyName campaign to the extent that its twitter account exhibited more than 14,000 tweets in less than a week of its first launch (Hausam, 2014) and bearing in mind, that in general social media campaigns follow different and shorter planning steps than the traditional campaign only: Set campaign goals, then Choose social networks then Engage with your campaign's participants then Display your collected content and finally Measure and analyze your campaign's success (Carnoy, 2016).

- Thequalitative analysis revealed discontinuation and irregular rhythm of broadcasting campaign messages via social media;thus denying the campaign the consistency feature that presents one of the main pillars characterizing any campaign; once again raising the question previously asked by researchers whether this and other pro-Islam social media campaigns are the latest in a long line of hashtag activism efforts, without effectively doing 
any tangible good in the long run.

RQ2: How are \#NotInMyName social media accounts utilized to act as pro-Islam platforms?

- \#NOTInMyName social media accounts were never launched from the start to display footage regarding campaign contributors expressing their resentment to ISIS's deeds and terrorist attacks. Rather it turned out to be a rich platform concerning controversial debates on Islam, Muslims, refugees and various governmental actions. This result is consistent with Uddin's (2014) quoting Wall Street Journal column as noticing that social media, and Twitter in particular, "offer[s] a unique tool to bring widespread visibility to issues and ideas within [and towards] community that have long been ignored by the general public".

- The heading of the campaign was used as an international icon in itself symbolizing denouncing every action that was a disgrace in one way or another from the viewpoints of followers of the hashtags.

- Not in my name "heading" was used extensively as a motto to launch different opinions in different matters that followers condemn, so "Not in my name" was used as a motto to combat racism or used as a motto to condemn bullying at schools or used as a motto by angry citizens defaming their nations one way or another.

- \#NotInMyName accounts were used as a platform for discussing several political issues, as if \#NOTInMyName was set to be an uprising platform against all unjust actions taking place in different parts of the world using the growing availability of user-generated viral videos discussing all sorts of controversies.

- The major finding was that the coverage of the campaign was more effective than the campaign itself, and that's the advantage of stirring issues via social media and this fact was apparent.

\section{Conclusion}

The major conclusion of this study was that proislam hashtags acquired unprecedented power to stir political and social movements especially, regarding controversial and stagnant matters. Posts, comments and shares on different social media platforms go viral, stir discussions, and trigger public opinion both virtually and in reality.

This campaign \#hashtags were not a launching base for the campaign as much as being an outlet breather for all pro and anti-opinions regarding not only Islam, but every other controversial matter taking place in the world at the time. Social media are now the pathway to mobilize the crowd online to take an action in the real world.

Since the new media can promote more inclusive social interaction that respects minorities and minority views (Balas et al., 2011), Muslims abroad - instead of using social media activism as mostly reactionary - Muslim social media activism needs to do more than stop bad speech; it also needs to help create good speech as Uddin (2014) emphasized.

Waiting to launch those hashtags after tragic and disastrous events ousts these efforts of their ultimate goals of image restoration and confines them to achieve temporary goals rather than permanent ones. A well planned activism effort that teaches people abroad the true meaning of Islam through employing well-organized long term objectives can be launched using social media and offline acculturation activities as the Islamic awareness weeks, lectures, advocacy... etc. in order to abandon the scant ineffective individual efforts to achieve more systematic collaborative endeavors maximizing the ultimate positive outcomes.

\section{References}

Ahmad, K. and Sheikh, K. S. (2013). "Social Media and youth participatory politics: A study of university students". South Asian Studies, 28(2). 353-360.

Al-Hamid, N. (25 May 2012). "Saudi conference urges promotion of Islam on social media". BBC Monitoring Middle East, London.

Aly, A. (2012). "An audience-focused approach to examining religious extremism online". Australian Journal of Communication. 39(1), 1-16.

Ameripour et al. (2010). "Conviviality of Internet social networks: An exploratory study of Internet campaigns in Iran". Journal of Information Technology, 25(2), 244-257.

Anonymous. "Using social media to communicate against violent extremism". Australian Government Living Safe TogetherReport, www. Livingsafetogether. gov.au

Anonymous. (1 Sept 2014). "About The MyJihad Campaign". http://myjihad.org/

Anonymous. (17 Nov 2015). "\#NotInMyName: Muslims condemn IS through Twitter campaign". SBS 
News

Anonymous. (25 May 2016). "CAIR Launches Satirical 'ISLAMOPHOBIN' Public Awareness Campaign to Challenge Anti-Muslim Bigotry". Council on AmericanIslamic Relations (CAIR), PR Newswire-US News-wire. Washington.

Anonymous. (28 Dec 2015). "America's Largest Muslim Organization Launches Campaign-True Islam and the Extremists, Invites all American Muslims to endorse campaign". http://trueislam.com.

Aragon, P. et al. (2013). "Communication dynamics in twitter during political campaigns: The case of the 2011 Spanish national election". Policy and Internet, 5(2), 183-206.

Balas, A. et al. (2011). "Social Media and future of leadership: Call for action in the Balkans". SocialAnalysis, 1(2), 154-166.

Barak, M. (Nov 2014). "Not in My Name - ISIS and protests against it as reflected on SNS". Bee Hive: Middle East Social Media, 2(10).

Bernstein, S. (16 June 2015). "Facing backlash, U.S. Muslims counter with new advertising campaign", Reuters.

Brickner, R. K. (2016). "Tweeting care: Educators' dissent through Social Media in the US and Canada". Labour, 77, 11-I

Brown, N. (17 Nov 2015). "Muslims use social media to condemn ISIS, fight Islamophobia". MSNBC News.

Cameron, A. M. et al. (2013). "Social Media and organ donor registration: The Facebook effect". American Journal of Transplantation, 13(8), 2059-2065.

Carlson, T. et al. (2014). "Taking risks in social media campaigning: The early adoption of blogging by candidates". Scandinavian Political Studies, 37(1), 2140.

Carnoy, J. (28 Apr 2016). "5 Tips for running your best Social Media campaign ever". Entrepreneur Middle East, https://www.entrepreneur.com/article/272231

Dowshen, N. et al. (2015). "IknowUshould2: Feasibility of a youth-driven Social Media campaign to promote STI and HIV testing among adolescents in Philadelphia". AIDS and Behavior, 19, 106-111.

Dunlop, S. et al. (2016). "Marketing to youth in the digital age: The promotion of unhealthy products and health promoting behaviors on Social Media". Media and Communication, 4(3).

Essert, M. (21 Sep 2014). "Young British Muslims Tell the Islamic State: \#NotInMyName". Mic. World.com

Faget, D. (15 Nov 2015). "\#NotInMyName Muslims Use Social Networks to Condemn Terror". Sputniknews.com.

Finnigan, J. and Ross, N. (2013). "I'm a Mormon feminist: How Social Media revitalized and enlarged a movement". Interdisciplinary Journal of Research on Religion, 9, 1-26

Furlow, N. E. (2011). "Find us on Facebook: How cause marketing has embraced Social Media". Journal of Marketing Development and Competitiveness, 5(6), 61-64.

Glover. S. (12 June 2016). "Coverage of the Orlando nightclub massacre". Chicago5

Gouvria, A. (14 June 2016). "\#NotInMyName: Muslims And The UAE Stand Up Against Orlando Attack". Emirateswomannews.com.

Hagar, D. (2014). "Campaigning online: Social Media in the 2010 Niagara municipal elections". Canadian Journal of Urban Research, 23(1), 74-98.

Harris, S. (3 July 2015). "\#MessageTolsis Campaign Encourages People To Speak Out In Defiance Against Isis". The Huffington Post.

Hausam, M. (2014). "Muslims speak out against ISIS as \#NotInMyName Social Media campaign Takes Off". http://www.ijreview.com.

Helmus, T. C. et al. (August 2011). "Promoting online voices for countering violent extremism". Rand Corporation Report, available at: www. rand.org.

Hoskinson, C. (26 Oct 2014). "Anti-Islamic state allies seek way to fight group's social media success". The Examiner, Washington, D.C.

Huesch, M. D. et al. (2016). "Using Social Media, online social networks, and internet search as platforms for public health interventions: A pilot study". Health Services Research, 51(S2), 1273-1290.

Inspired by Muhammad.com. http://www. inspiredbymuhammad.com/campaign.php 
Jawad, M. et al. (2015). "Social Media use for public health campaigning in a low resource setting: The case of waterpipe tobacco smoking". BioMed Research International, volume 2015.

Ketter E. and Avraham, E. (2012). "The social revolution of place marketing: The growing power of users in social media campaigns". Place Branding and Public Diplomacy, 8(4), 285-294.

Livingston, J. D. et al. (2014). "Another time point, a different story: one year effects of a social media intervention on the attitudes of young people towards mental health issues". Social Psychiatry and Psychiatric Epidemiology, 49(6), 985-990.

Meredith, C. (25 Sept 2014). "British Muslims Rejecting Islamic State With \#NotInMyName Campaign Praised By Barack Obama At UN General Assembly". Huffington Post UK.

Özdemir, B. P. (2012). "Social Media as a tool for online advocacy campaigns: Greenpeace Mediterranean's anti genetically engineered food campaign in Turkey". Global Media Journal, 5(2), 23.

Pillai, P. (2012). "Healthcare social media strategy: Using social media to improve healthcare business insights on current practice and future promise". International Journal of Management Research and Reviews, 2(5), 792-799.

Pratt, S. (18 Nov 2015). "NotInMyName: Muslims condemn attacks in Paris". CNN News.

Sfondeles T. (14 Dec 2012). "Local Muslim group reclaiming 'Islam' with 'MyJihad' campaign". Chicago Sun Times.

Sisto, C. (23 Sept 2014). "In new \#NotInMyName campaign, British Muslims denounce the Islamic State". Corner Blog Magazine.http://www. nationalreview.com/article/388593/moderatemuslims-stand-against-isis-christine-sisto.

Spierings, N. and Jacobs, K. (2014). "Getting personal? The Impact of Social Media on preferential voting". Political Behavior, 36(1), 215-234.

Talev, M. (28 Aug 2010). "Why so many Americans are hostile toward Islam". SaintPaul, Minn.

Tilson, D. J. (2011). "Public Relations and religious diversity: A conceptual framework for fostering a spirit of Communitas". GlobalMedia Journal, 4(1).
Uddin, A. (25 Apr 2014). "Minority communities and the mighty tweet". Institute for Social Policy and Understanding, http://www.ispu.org/ content/minority_communities_and_the_mighty_ tweet\#sthash.XXW7BK70.dpuf

Wells, C. et al. (2016). "Coproduction or cooptation? Real-time spin and social media response during the 2012 French and US presidential debates". French Politics, 14(2), 206-233.

Zahra, I. (2018). Utilizing the dimensions of religion to analyze social media campaigns. In M. N. Saqri et al. (Eds.), Promoting interdisciplinarity in knowledge generation and problem solving (pp.202-220). PA: IGI Global

Zimmerman, J. W. and Brown, D. (2012). The Complete Idiot's Guide To Facebook Marketing. New York: Alpha. 
